\title{
Sawdust-kaolinite composite as efficient sorbent for heavy metal ions
}

\author{
I. C. Ogbu ${ }^{1 *}$, K. G. Akpomie ${ }^{2}$, A. A. Osunkunle ${ }^{1}$, S. I. Eze \\ ${ }^{1}$ Materials and Energy Technology (MET) Department, Projects Development Institute (PRODA), Enugu, Nigeria \\ ${ }^{2}$ Department of Pure \& Industrial Chemistry, University of Nigeria, Nsukka, Nigeria
}

Received: 26 December 2017

Revised: 11 February 2018

Accepted: 23 May 2018

DOI: https://doi.org/10.3329/bjsir.v54i1.40736

\begin{abstract}
The improvement of the adsorption capacity of clay minerals using chemicals though effective is expensive, results in secondary contamination and noxious to the environment. This study was therefore aimed at the development of a new sawdust clay modified adsorbent (SDKC) as an alternative means of improving the adsorption capacity of kaolinite. The adsorbents were characterized by the Fourier transform infrared spectroscopy and X-ray diffraction analysis. Batch sorption was employed to determine the effect of $\mathrm{pH}$, metal concentration, sorbent dose, time and temperature on the removal of $\mathrm{Pb}$ (II) and $\mathrm{Cd}$ (II) ions from solution by the adsorbents. Optimum operating conditions of $\mathrm{pH} 6.0$, metal concentration $200 \mathrm{mg} / \mathrm{L}$, sorbent dose $0.1 \mathrm{~g}$ was obtained. Equilibrium isotherm analysis indicated the Langmuir, Temkin and Flory-Huggins models to be more suitable than the Freundlich, Dubinin-Radushkevich (D-R). The kinetic data were analyzed using the pseudo-first order, pseudo-second order, the Elovich and intraparticle diffusion models. The analysis revealed that the adsorption process followed pseudo second order model. The calculated thermodynamic parameters showed an endothermic, spontaneous and a physisorption process between both metal ions and the adsorbents. The obtained result of the experiment indicated a significant improvement in the uptake of $\mathrm{Pb}$ (II) and $\mathrm{Cd}$ (II) ions on the sawdust modified kaolinite adsorbent than the untreated kaolinite clay. This could be utilized as an alternative to chemical treatment methods
\end{abstract}

Keywords: Heavy metals; Sawdust-kaolinite composite; New adsorbents; Characterization

\section{Introduction}

Environmental degradation as a result of pollution with toxic substances has been on the increase in recent years due to rapid growth of industries. This rapid growth of industries has resulted to an increase in discharge of wastewaters containing heavy metals, which is a serious environmental problem. These heavy metals are usually toxic at certain concentrations to living organisms, persistent in nature, non-biodegradable and tend to accumulate in the food chain (Ahluwalia and Goyal, 2007). It is therefore necessary to remove these metals from industrial effluents before their discharge into receiving water bodies. The heavy metals present in solutions commonly include $\mathrm{Pb}, \mathrm{Cd}, \mathrm{Zn}, \mathrm{Cu}, \mathrm{Ni}$, $\mathrm{Cr}, \mathrm{Mn}, \mathrm{Fe}, \mathrm{Hg}$ and As (El-Eswed et al., 2012). Cadmium is a potent enzyme inhibitor and causes kidney and liver damages in animals and humans (Politi and Sidiras, 2012). Cadmium is responsible for kidney tubular impairment, affects ion regulation, calcium metabolism and skeletal calcification. Cadmium poisoning also causes severe abdominal pain, vomiting, diarrhea and a choking sensation. Lead is a general metabolic poison, enzyme inhibitor and affects the functioning of the blood, liver, kidney and brains of humans; it can also cause behavioral problems, learning disabilities, seizures and death (Guerra et al., 2013; Farghali et al., 2013). The permissible level for lead in drinking water is $0.05 \mathrm{mg} / \mathrm{L}$.

*Corresponding author e-mail: ikeokwuogbu@yahoo.com 
The permissible level for lead in drinking water is $0.05 \mathrm{mg} / \mathrm{L}$. The permissible limit $(\mathrm{mg} / \mathrm{L})$ for $\mathrm{Pb}(\mathrm{II})$ in wastewater according to Bureau of Indian Standards (BIS) is $0.1 \mathrm{mg} / \mathrm{L}$. (BIS, 1981).The recommended limits for $\mathrm{Pb}$ (II) and $\mathrm{Cd}$ (II) in drinking water as per World Health Organization (WHO) are $0.010 \mathrm{mg} / \mathrm{L}$ (Lalhruaitluanga et al., 2010 ) and 0.005 $\mathrm{mg} / \mathrm{L}$ (Solisio et al., 2008) respectively. Therefore, it is of great relevance to remove lead and cadmium from aquatic environment using biosorbents. Therefore, the concentrations of these metals must be reduced to levels that satisfy environmental regulations for various bodies of water.

The conventional methods for removing lead and cadmium from wastewater include membrane filtration, chemical precipitation, ion-exchange, chelation, reverse-osmosis, solvent extraction, evaporation, electroplating and adsorption (Sari and Tuzen, 2009). Among these, adsorption is effective and economical (Ahmad et al., 2009). Many heavy metal adsorption studies have focused on the application of activated carbons (Kikuchi et al., 2006; Malik et al., 2002). However, it is quite expensive with relatively high operating costs. Hence there is a growing demand to find low cost and efficient adsorbents to remove heavy metals from aqueous solution. Recently, many industrial, agricultural and forestry sources are used as biosorbents such as, sawdust (Shukla and Roshan, 2005), clay (Akpomie et al., 2012), zeolite (Biserka and Boris, 2004), kaolinite (Chantawong et al., 2001), illite (Echeverria et al., 2005), sepiolite (Brigatti et al., 2000), biomass materials ( Kiran et al., 2005; Ucun et al., 2003; Jionlong et al.,C 2001; Marshal and Champagne, 1995), soil (Das and Mondal, 2011), montmorillonite (Barbier et al., 2000) and bentonite (Naseem and Tahir, 2001). Nigeria is abundantly rich in clay minerals which can be used as cheap alternative adsorbent for the removal of heavy metals from solution. However, clay minerals usually have low adsorption capacity, but its modification with acids or alkaline have greatly improved the adsorption capacity due to the removal of impurities and increasing in surface area of clays (Akpomie and Dawodu, 2014). Unfortunately, the use of these chemicals for modification is expensive and leads to secondary contamination. Therefore, it is necessary to look for other low cost alternative means of clay modification for improving the adsorption capacity for heavy metals. In this study, the use of sawdust to modify kaolinite (sawdust-kaolinite composite), being a novel adsorbent for the removal of $\mathrm{Pb}$ (II) and $\mathrm{Cd}$ (II) ions from contaminated solution was investigated. The sawdust is also very cheap as clay and is present in large quantity in Emene, Enugu east local government area, Enugu State, Nigeria. Batch adsorption technique was applied and the effect of solution $\mathrm{pH}$, initial metal ion concentration, adsorbent dose, agitating time and temperature were investigated. Equilibrium, kinetic and thermo-dynamic parameters were also determined to help provide a better understanding of the sorption process.

\section{Materials and methods}

\section{Preparation of adsorbents}

The Kaolinite clay was purchased from Aloji in Kogi state of Nigeria. It was dissolved in excess de-ionized water in a pretreated plastic container with proper stirring to ensure proper dissolution and after which it was filtered through a $300 \mu \mathrm{m}$ sieve and the filtrate allowed to settle for $24 \mathrm{hrs}$. The excess water was decanted and the clay residue sundried for several days, and then dried in an oven at $105^{\circ} \mathrm{C}$ for $4 \mathrm{hrs}$. The dried clay was pulverized and passed through $100 \mu \mathrm{m}$ mesh sieve to obtain the Kaolinite Clay (KC). The saw dust was obtained from a saw mill in Enugu state of Nigeria. It was then washed with de-ionized water to remove unwanted materials more especially heavy metals attached to the surface. The saw dust was sundried for several days, after which it was ground or pulverized to powdery form. The sample was then passed through $100 \mu \mathrm{m}$ mesh sieve to obtain the saw dust (SD). To prepare the composite adsorbent, the kaolinite was modified with saw dust using the method described by Akpomie and Dawodu (2014b). The raw saw dust was added to the raw clay at a ratio of 10:90, 20:80, 30:70, 40:60 and 50:50 by weight. Distilled water was added to form a solid paste of the mixture, which was compounded using a pestle and a mortar to aid the coming together of the particles and to ensure proper blending. After a while, it was sundried, pulverized and heated in a muffle furnace at $300^{\circ} \mathrm{C}$ and passed through $100 \mu \mathrm{m}$ mesh sieve to obtain the saw dust-kaolinite clay (SDKC) composite adsorbent.

\section{Preparation of adsorbates}

A laboratory solution of lead (II) and Cadmium (II) ions were prepared by dissolving appropriate amounts of $\mathrm{Pb}\left(\mathrm{NO}_{3}\right)_{2}$ and $\mathrm{Cd}\left(\mathrm{NO}_{3}\right)_{2}$, respectively in a beaker. Thereafter, the solution was placed in 1 liter volumetric flask and made up to the meniscus mark with de-ionized water to obtain a stock solution of concentration $1000 \mathrm{mg} / \mathrm{L}$ of the metal ions. Several lower concentrations of the metal ions which include $200,400,600$, and $800 \mathrm{mg} / \mathrm{L}$ were then prepared from the stock solution by serial dilution.

\section{Physicochemical characterization}

The physicochemical analysis of the solution was determined using standard methods (AOAC, 2005) by the use of analytical grade chemicals obtained from Sigma Aldrich. The heavy metal concentration of the solution was determined by 
the use of the Atomic Absorption Spectrophotometer (AAS) (Buck scientific model 210VGP).X-ray diffraction (XRD) analysis was determined using a model MD 10 Randicon diffractometer operating at $25 \mathrm{kV}$ and $20 \mathrm{~mA}$. The scanning regions of the diffraction were $16-72{ }^{\circ} \mathrm{C}$ on the 2 angle. The Fouriertransforminfrared spectrophotometer (FTIR; Shimadzu 8400s) was used to investigate the surface functional groups on the adsorbents, while scanning electron microscope (SEM; HitachS4800) was utilized to access the morphology.

\section{Batch adsorption studies}

Batch adsorption experiment was performed to determine the effect of $\mathrm{pH}$, initial metal ion concentration, adsorbent dose, temperature and agitation time. The experiment was performed by adding $0.1 \mathrm{~g}$ of the adsorbent to $20 \mathrm{ml}$ of a given solution in a pretreated glass bottle at room temperature of $300 \mathrm{~K}$. The influence of $\mathrm{pH}(2.0-8.0)$ studied by varying the $\mathrm{pH}$ of the solution by the drop wise addition of $0.1 \mathrm{M} \mathrm{HCl}$ or $0.1 \mathrm{M} \mathrm{NaOH}$, initial metal concentration $(200,400,600$, 800 and $1000 \mathrm{mg} / \mathrm{L})$, adsorbent dose $(0.1,0.2,0.3,0.4$ and 0.5 $\mathrm{g})$, agitation time $(10,20,30,40,50,60,90$ and $120 \mathrm{~min})$ and temperature $(300,313,323 \mathrm{~K})$ were evaluated. The bottles were placed in a thermo-stated water bath for temperature regulation when the effect of temperature was studied. In order to evaluate the effect of a particular parameter, that parameter was varied while others were kept constant at the optimum conditions. At the end of the given agitation time for a particular sorption, the mixed solution was filtered and the residual metal ion concentration in the filtrate was determined by the AAS. The following equations were utilized in the calculation of percentage removal of metal ions and the adsorption capacity of the adsorbent for metal ions respectively:

$$
\begin{aligned}
& \text { Removal }(\%)=\frac{100\left(C_{0}-C_{e}\right)}{C_{0}} \\
& \mathrm{q}_{e}(m g / g)=v \frac{\left(C_{0}-C_{e}\right)}{m}
\end{aligned}
$$

where $q e(\mathrm{mg} / \mathrm{g})$ is the adsorption capacity, $C o(\mathrm{mg} / \mathrm{L})$ is the initial metal ion concentration in solution, $C e(\mathrm{mg} / \mathrm{L})$ is the metal ion concentration remaining in solution at equilibrium, $v$ (litres) represents the volume of solution used for the adsorption and $m(\mathrm{~g})$ is the mass of the adsorbent used.

\section{Isotherm modeling}

The equilibrium isotherm modeling was carried out by the application of the Langmuir, Freundlich, Temkin and Dubinin-Radushkevich (D-R), Scatchard and Flory-Huggins isotherm model presented in the equations respectively (Langmuir, 1918).

$$
\begin{aligned}
& \frac{\mathrm{C}_{\mathrm{e}}}{\mathrm{q}_{\mathrm{e}}}=1 / \mathrm{q}_{\mathrm{L}} \mathrm{K}_{\mathrm{L}}+\mathrm{C}_{\mathrm{e}} / \mathrm{q}_{\mathrm{L}} \\
& \log \mathrm{q}_{\mathrm{e}}=\log \mathrm{K}_{\mathrm{F}}+[1 / \mathrm{n}] \log \mathrm{C}_{\mathrm{e}} \\
& \mathrm{q}_{\mathrm{e}}=\mathrm{B} \ln \mathrm{A}+\mathrm{B} \ln \mathrm{C}_{\mathrm{e}} \\
& \ln _{\mathrm{e}}=\ln \mathrm{q}_{\mathrm{m}}-\beta \varepsilon^{2} \\
& \mathrm{q}_{\mathrm{e}} / \mathrm{C}_{\mathrm{s}}=\mathrm{q}_{\mathrm{s}} \mathrm{b}-\mathrm{q}_{\mathrm{e}} \mathrm{b} \\
& \log \left(\theta / \mathrm{C}_{\mathrm{i}}\right)=\log \mathrm{K}_{\mathrm{FH}}+\mathrm{nFH \operatorname {log }}(1-\theta)
\end{aligned}
$$

Where qe $(\mathrm{mg} / \mathrm{g})$ and $\mathrm{K}_{\mathrm{L}}(\mathrm{L} / \mathrm{mg})$ are related to the adsorption capacity and energy of adsorption respectively. $K_{F}(\mathrm{~L} / \mathrm{g})$ and $n$ are Freundlich adsorption constants representing the adsorption capacity and intensity of the adsorbent respectively. $B=R T / b_{T}, T$ is the temperature $(\mathrm{K}), R$ is the ideal gas constant $(8.314 \mathrm{~J} / \mathrm{mol} \mathrm{K})$ and $A$ and $b_{T}$ are Tempkins constants. $q_{m}(\mathrm{mg} / \mathrm{g})$ is the theoretical saturation capacity, $\beta$ $\left(\mathrm{mol}^{2} / \mathrm{J}^{2}\right)$ is a constant related to the mean free energy of adsorption per mole of the adsorbate and $\varepsilon$ is the Polanyi potential ()$\cdot \mathrm{q}_{\mathrm{S}}(\mathrm{mg} / \mathrm{g})$ and $\mathrm{b}(\mathrm{L} / \mathrm{mg})$ represent the Scatchard isotherm sorption parameters. $\theta=\left(1-\mathrm{Ce} / \mathrm{C}_{\mathrm{i}}\right)$ is the degree of surface coverage, $\mathrm{K}_{\mathrm{FH}}(\mathrm{L} / \mathrm{g})$ and $\mathrm{n}_{\mathrm{FH}}$ represent the Flory-Huggins equilibrium isotherm constant and model exponent, respectively

\section{Kinetic modeling}

The kinetic modeling was carried out by the application of the pseudo-first order, pseudo-second order, Elovich equation and intraparticle diffusion models represented in the given equations respectively (Low, 1960; Taffarel and Rubio, 2009):

$$
\begin{aligned}
& \log \left(\mathrm{q}_{\mathrm{e}}-\mathrm{q}_{\mathrm{t}}\right)=\log \mathrm{q}_{\mathrm{e}}-\left(\mathrm{K}_{\mathrm{l}} \mathrm{t} / 2.303\right) \\
& \mathrm{t} / \mathrm{q}_{\mathrm{t}}=1 / \mathrm{K}_{2} \mathrm{q}_{\mathrm{e}}{ }^{2}+\mathrm{t} / \mathrm{q}_{\mathrm{e}} \\
& \mathrm{q}_{\mathrm{t}}=[1 / \beta] \ln (\alpha \beta)+[1 / \beta] \ln \mathrm{t} \\
& \mathrm{q}_{\mathrm{t}}=\mathrm{K}_{\mathrm{d}} \mathrm{t}^{1 / 2}+\mathrm{C}
\end{aligned}
$$


Where qt $(\mathrm{mg} / \mathrm{g})$ and qe $(\mathrm{mg} / \mathrm{g})$ are the amounts of metal ions adsorbed at time $t$ and equilibrium, respectively. $K_{I}$ is the pseudo-first order adsorption rate constant $\left(\mathrm{min}^{-1}\right) . \mathrm{h}=\mathrm{K}_{2} \mathrm{qe}^{2}$ is the initial sorption rate $(\mathrm{mg} / \mathrm{g} \min ), \mathrm{K}_{2}(\mathrm{~g} / \mathrm{mg} \mathrm{min})$ is the rate constant of pseudo second order reaction. $\alpha$ is the initial sorption rate constant $(\mathrm{mg} / \mathrm{g} \mathrm{min})$ and the parameter $\beta$ is related to the extent of surface coverage and the activation energy for chemisorptions $(\mathrm{g} / \mathrm{mg}) . \mathrm{K}_{\mathrm{d}}\left(\mathrm{mg} / \mathrm{gmin}{ }^{1 / 2}\right)$ is the intraparticle diffusion rate constant and $\mathrm{C}$ represents the intercept. If the plot of $\mathrm{q}_{\mathrm{t}}$ versust $^{1 / 2}$ is linear then the intraparticle diffusion is involved in the mechanism (Guler and Sarioglu, 2013).

\section{Adsorption thermodynamics}

The thermodynamic parameters such as the standard free energy $\left(\Delta G^{\circ}\right)$,enthalpy change $\left(\Delta H^{\circ}\right)$ and entropy change $(\Delta$ $\left.S^{\circ}\right)$ were determined to evaluate the feasibility of adsorption by the application of the following equations (Dawodu and Akpomie, 2014)

$$
\begin{aligned}
& \Delta \mathrm{G}^{\mathrm{O}}=-\mathrm{RT} \ln \mathrm{K}_{\mathrm{c}} \\
& \ln \mathrm{K}_{\mathrm{c}}=-\left(\Delta \mathrm{H}^{\mathrm{o}} / \mathrm{RT}\right)+\left(\Delta \mathrm{S}^{\mathrm{o}} / \mathrm{R}\right)
\end{aligned}
$$

where $\mathrm{Kc}=\mathrm{Ca} / \mathrm{Ce}$ is the distribution coefficient, $\mathrm{Ca}(\mathrm{mg} / \mathrm{L})$ and $\mathrm{Ce}(\mathrm{mg} / \mathrm{L})$ represent the concentration of heavy metals adsorbed and that remaining in solution at equilibrium, respectively. $T(K)$ is the absolute temperature and $\mathrm{R}$ is the gas constant. $\left(\Delta H^{\circ}\right)$ and $\left(\Delta S^{\circ}\right)$ were evaluated from the slope and intercept of the linear plot of $\operatorname{lnKc}$ versus $1 / \mathrm{T}$.

\section{Results and discussion}

Selection of optimum sawdust-kaolinite clay adsorbent

In order to select the appropriate mixing ratio for kaolinite and sawdust, five composites were prepared which comprises of $10 \%$ sawdust and 90\% kaolinite clay (10SD-90KC), 20\% sawdust and 80\% kaolinite clay (20SD-80KC), 30\% sawdust and $70 \%$ kaolinite clay (30SD-70KC), 40\% sawdust and $60 \%$ kaolinite clay (40SD-60KC) and 50\% each of sawdust and kaolinite clay $(50 \mathrm{SD}-50 \mathrm{KC})$. The adsorbents were utilized for the adsorption of the metal ions from the binary solution at a metal concentration of $200 \mathrm{mg} / \mathrm{L}$ as shown in Fig. 1. From the graph it was observed that the addition of sawdust increased the adsorption potential of the kaolinite compared to when the kaolinite was used alone (100KC). An increase in percentage removal of both metal ions with increase in the amount of sawdust in the composite was noticed. Optimum adsorption of $\mathrm{Pb}(94.95 \%$ and $37.98 \mathrm{mg} / \mathrm{g})$ and $\mathrm{Cd}(90.9 \%$ and 36.36 $\mathrm{mg} / \mathrm{g}$ ) was obtained using the 50SD-50KC adsorbent. The increase in metal adsorption with SD concentration is simply due to increase in the number of active binding (Akpomie and Dawodu, 2014b). The 50SD-50KC adsorbent was then chosen and utilized in this study for adsorption due to its higher percentage removal recorded than the other composites.

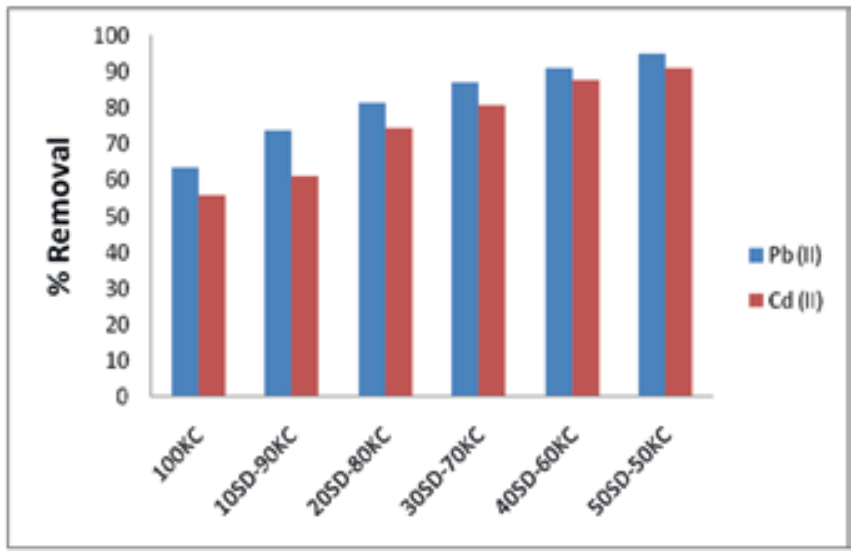

Fig. 1. Effect of sawdust addition to kaolinite and calcination on the percentage adsorption of heavy metals ( $\mathrm{pH}$ 6.0, dosage $0.1 \mathrm{~g}$, temperature $300 \mathrm{~K}$, metal concentration $200 \mathrm{mg} / \mathrm{L}$, contact time $120 \mathrm{~min}$ )

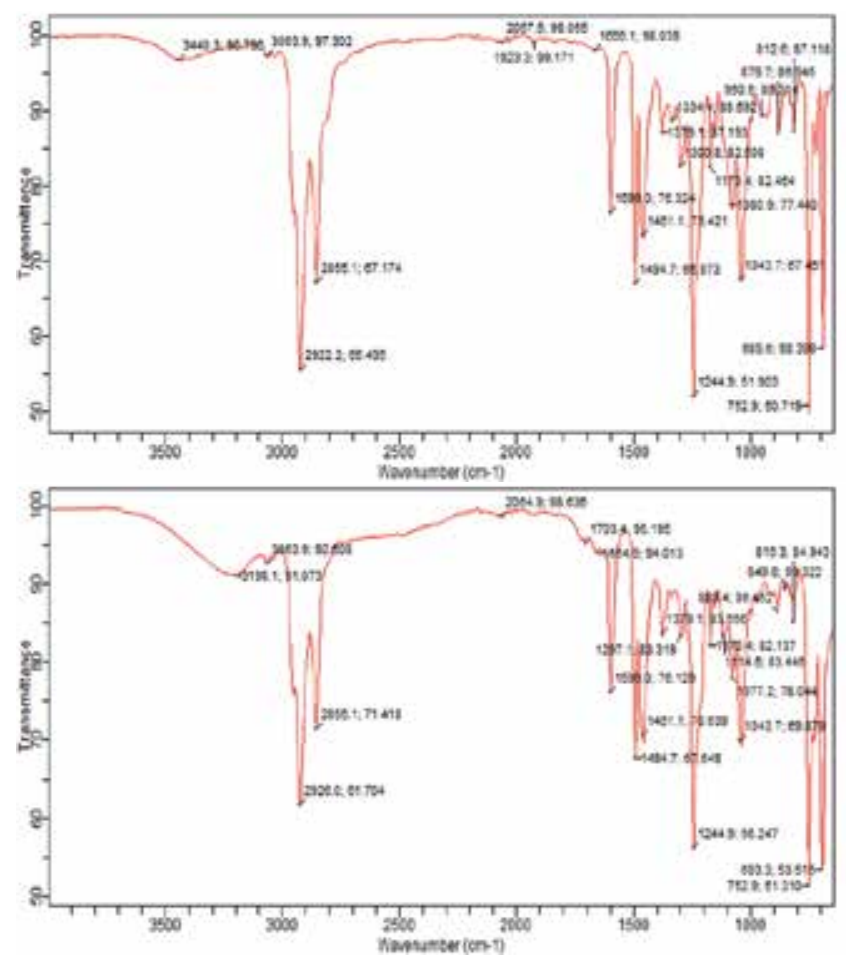

Fig. 2. Fourier transform infrared spectra of (a) kaolinite clay (b) calcined sawdust-kaolinite composite 


\section{FTIR and SEM analysis}

The adsorbents were characterized to evaluate the surface nature and functional groups, the mineral identification and the morphology of the adsorbents using the Fourier Transform Infrared (FTIR) spectroscopy and Scanning Electron microscopy (SEM) respectively. The spectra illustrating the characterization of the adsorbents are shown in Fig. 2 and 3. The FT-IR analysis is useful in the spectrophotometric observation of adsorbent surface within the range of $400-4000 \mathrm{~cm}^{-1}$ and therefore assist in the identification of the functional groups on the surface. A close examination of the adsorbent surface before and after modification provides information regarding the surface groups involved in the modification and confirms the modification of the adsorbent. The FT-IR spectrum of $\mathrm{KC}$ is shown in Fig 2a; several bands were observed which suggest that the kaolinite is composed of various functional groups responsible for binding of metal ions. Absorption bands at $3440.3 \mathrm{~cm}^{-1}$ corresponds to the outer surface $\mathrm{OH}$ stretching vibration of kaolinite (Dawodu and Akpomie, 2014). The band at $2057.5-2922.2 \mathrm{~cm}^{-1}$ represents the $\mathrm{P}-\mathrm{OH}$ stretching vibration, while bands at $1334.0-1666.1 \mathrm{~cm}^{-1}$ are due to the $\mathrm{OH}$ bending vibration of water and can also be attributed to the symmetric COO stretching vibration ( $\mathrm{Li}$ et al, 2013). The Si-O bending vibration was observed at $1043.7-1170.4 \mathrm{~cm}^{-1}$ while the stretching vibration was observed at $752.9 \mathrm{~cm}^{-1}$ $689.6 \mathrm{~cm}^{-1}$ (Dawodu and Akpomie, 2014). The FTIR spectrum of SDKC is shown in Fig $2 b$, changes in the absorption bands of the kaolinite after sawdust modification were observed in the spectrum which is an indication of the successful modification of the adsorbent. The $\mathrm{P}-\mathrm{OH}$ stretching bands were also observed at $2064.9-2064.9 \mathrm{~cm}^{-1}$, while the $\mathrm{OH}$ bending vibration of water or the symmetric COO stretching was observed at $1297.1-1654.9 \mathrm{~cm}^{-1}$. The Si-O bending vibration was observed at $1043.7-1170 \mathrm{~cm}^{-1}$. The Si-O stretching vibration of the sawdust-kaolinite was also observed by bands at $693.3-752.9 \mathrm{~cm}^{-1}$ (Dawodu and Akpomie, 2014).

Scanning electron microscopy (SEM) of the adsorbents are shown in Fig 3. The SEM is used to examine the surface morphology and the porous nature of the material responsible for adsorption of metal ions. From the SEM images, it is observed that the adsorbents revealed a porous nature, considerable number of heterogeneous pores, an irregular surface and particle aggregation of various shapes and sizes (Meitei and Prasad, 2013). The presence of pores helps in the diffusion of metal ions into the adsorbents during the sorption of metal ions from solution (Dawodu and Akpomie, 2014. However, an increase in porosity of SDKC was observed in the SEM images when compared to $\mathrm{KC}$ and may suggest higher removal of metal ions by SDKC than KC. Also, the SEM image of $\mathrm{KC}$ showed some white clumps or particles on the surface, these were probably due to the presence of non-clay minerals like potassium, iron, magnesium, sodium, calcium and manganese (Unuabonah, 2007). In general, the porous nature of the adsorbents more especially the composite (SDKC) revealed their suitability for adsorption of $\mathrm{Pb}$ (II) and $\mathrm{Cd}$ (II) from aqueous solution.

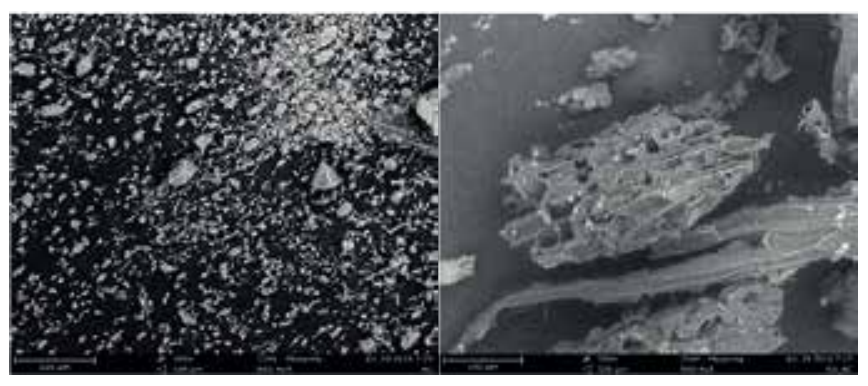

Fig. 3. Scanning electron microscopy of (a) kaolinite clay (b) calcined sawdust-kaolinite composite

\section{Effect of solution $\mathrm{pH}$}

The $\mathrm{pH}$ of the solution has an important effect on heavy metals sorption since the $\mathrm{pH}$ of the solution controls the magnitude of electrostatic charges and the degree of ionization of the adsorbate (Abdelwahab and Amin, 2013). Therefore, the amount of metal adsorbed will vary with the $\mathrm{pH}$ of an aqueous medium. The effect of $\mathrm{pH}$ on the simultaneous adsorption of $\mathrm{Pb}$ (II) and $\mathrm{Cd}$ (II) ions unto the adsorbent is shown in Fig.4. It was observed that the percentage removal of both metal ions on all the adsorbents showed an increase with increase in initial $\mathrm{pH}$ of solution. With an increase in initial $\mathrm{pH}$ of solution from 2.0 to 8.0 , the

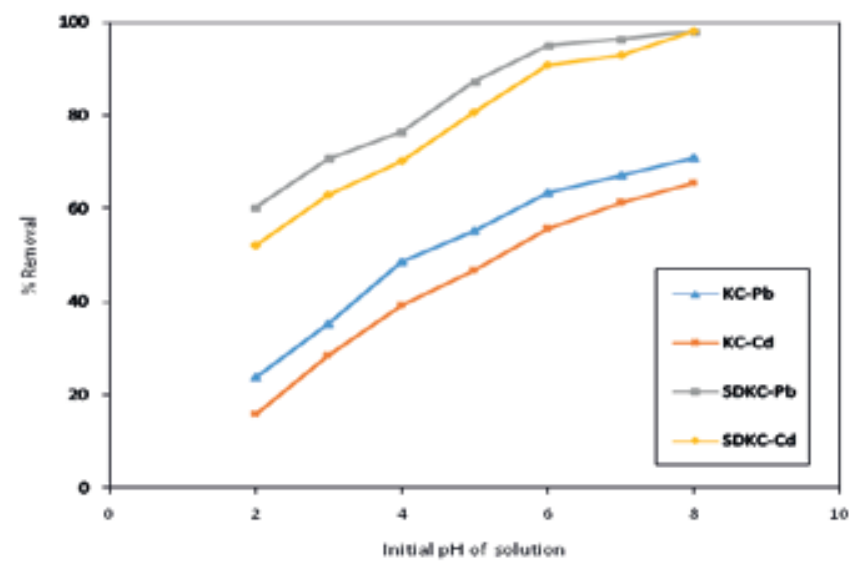

Fig. 4. Effect of initial pH of solution on the percentage removal of heavy metals ( Dosage $0.1 \mathrm{~g}$, temperature 300K, metal concentration $200 \mathrm{mg} / \mathrm{L}$, contact time $120 \mathrm{~min}$ ) 
percentage removal of $\mathrm{Pb}$ (II) increased from 23.7 to $67.1 \%$ and 60.3 to $97.95 \%$, for $\mathrm{KC}$ and $\mathrm{SDKC}$, respectively. Similarly, with an increase in the initial $\mathrm{pH}$ of solution from 2.0 to 8.0 , the adsorption of Cd (II) showed a percentage increase from 15.8 to $65.45 \%$ and 52.1 to $97.95 \%$. The low adsorption recorded at lower $\mathrm{pH}$ values is simply due to excess $\mathrm{H}^{+}$ions in solution which competes with the metal ions for the active sites of the adsorbent, resulting in a low removal. As $\mathrm{pH}$ of the solution increases, the concentration of $\mathrm{H}^{+}$ions in solution decreases, this reduces the competition between the metal ions and $\mathrm{H}^{+}$ions for the active sites of the adsorbents leading to an increase in percentage removal of metal ions. Notably, at $\mathrm{pH}>6.0$, metal ions may precipitate from solution in the form of hydroxides (Taffarel and Rubio, 2009). Therefore, precipitation may have accounted for some of the metal ions adsorbed, especially at higher $\mathrm{pH} 7.0$ and 8.0.The $\mathrm{pH}$ value of 6.0 was chosen in this study for all subsequent experiments and not 8.0, despite the highest removal obtained at 8.0. This was done in order to avoid metal precipitation associated with higher $\mathrm{pH}$ values (7.0-8.0) and ensure that adsorption phenomena accounted for the optimum adsorption recorded at 6.0. Furthermore, comparing the adsorption potential of the two adsorbents for metal ions, it was found that at all $\mathrm{pH}$ values for both $\mathrm{Pb}$ (II) and $\mathrm{Cd}$ (II) ions, the adsorption followed the order $\mathrm{SDKC}>\mathrm{KC}$. This result obviously showed that the addition of $\mathrm{SD}$ to $\mathrm{KC}$ and calcinations would improve the adsorption of the clay which is desired in this research. This is expected since biomass materials usually have higher adsorption potentials than clay minerals. Similar result on improving the adsorption capacity of clay using rice husk and has been reported (Akpomie and Dawodu, 2014). The increase in adsorption potential of SDKC when compared to $\mathrm{KC}$ is simply as a result of increase in the effective active sites and increase in the heterogeneous nature of the composite.

Also, comparing the adsorption of the two metal ions at all $\mathrm{pH}$ values on the two adsorbents, the following trend was observed $\mathrm{Pb}$ (II) $>\mathrm{Cd}$ (II). The difference in this adsorption trend of $\mathrm{Pb}$ (II) and $\mathrm{Cd}$ (II) may be attributed to differences in behavior of these metals or their ions in solution (Barka et al, 2013). The difference in the adsorption trend of $\mathrm{Pb}$ (II) and $\mathrm{Cd}$ (II) may be as a result of differences in behavior of these metals or their ions in solution. These include the smaller hydrated radius of $\mathrm{Pb}$ (II) $(0.401 \mathrm{~nm})$ compared to $\mathrm{Cd}$ (II) $(0.426 \mathrm{~nm})$, the higher electronegativity of $\mathrm{Pb}$ (II) (2.10) than $\mathrm{Cd}$ (II) (1.69), whereas $\mathrm{Pb}$ (II) is adsorbed as hydrolysed species Cd (II) is not. These factors accounts for the higher adsorption of lead than cadmium on adsorbents (Barka et al, 2013). Similar result has been reported (Nessim et al, 2014).

\section{Effect of initial metal ion concentration}

The investigation of initial metal ion concentration is a very important in adsorption studies, as most contaminated wastewaters usually have different concentration of metal ions, and therefore, the determination of its effect is necessary for an elaborate adsorption study. The effect of initial metal ion concentration on the percentage removal and adsorption capacity of $\mathrm{Pb}$ (II) and $\mathrm{Cd}$ (II) ions on $\mathrm{KC}$ and SDKC are shown in Fig. 5. A decrease in percentage removal of both metal ions on the adsorbents with increase in initial metal ion concentration was observed. This decrease in percentage removal is due to the fact that at lower concentrations, more of the metal ions would be removed by the abundant active sites on the adsorbent. At higher concentrations, more metal ions would be left un-adsorbed due to saturation of the active sites of the adsorbents. Unlike the decrease observed in percentage removal, an increase in adsorption capacity for both metal ions on all the adsorbents with increase in initial metal ion concentration was recorded. The increase in adsorption capacity of $\mathrm{Pb}$ (II) from 25.32 to $80.34 \mathrm{mg} / \mathrm{g}$ and 37.98 to $121.52 \mathrm{mg} / \mathrm{g}$ for $\mathrm{KC}$ and SDKC respectively and also increase in adsorption capacity of Cd (II) from 22.26 to $75.72 \mathrm{mg} / \mathrm{g}$ and 36.36 to $112.04 \mathrm{mg} / \mathrm{g}$ for $\mathrm{KC}$ and SDKC respectively with increase in metal ion concentration from 200 to $1000 \mathrm{mg} / \mathrm{L}$ was observed. This was attributed to the increasing concentration gradient which acts as a driving force to overcome the resistances to mass transfer of metal ions between the aqueous and solid phase (Kumar and Tamilarasan 2013). In fact, higher concentration in solution implies higher metal ions fixed at the surface of the adsorbent and maximum utilization of the active sites (Barka et al., 2013). The adsorption of metal ions on the adsorbents at all concentrations also followed the order SDKC $>\mathrm{KC}$, while the metal ions adsorption on by the adsorbents followed the trend $\mathrm{Pb}>\mathrm{Cd}$. The metal concentration of $200 \mathrm{mg} / \mathrm{L}$ was utilized in this study due to the high percentage removal recorded.

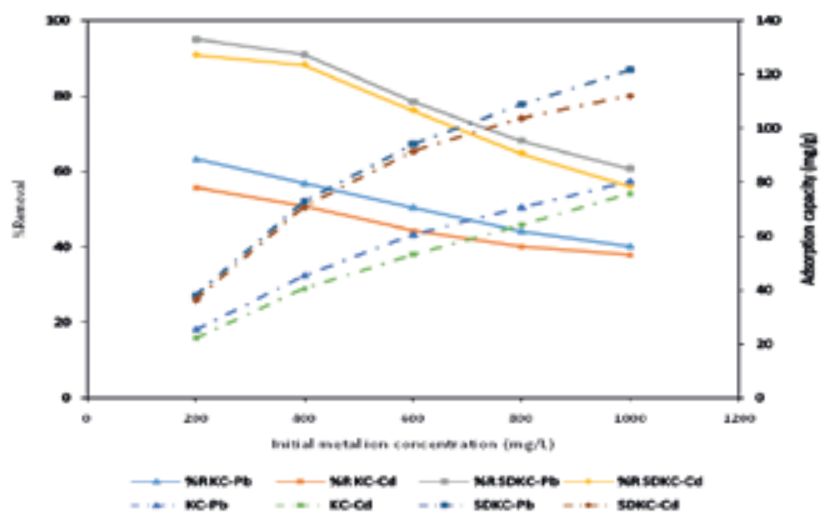

Fig. 5. Effect of initial metal ion concentration on the adsorption of heavy metals (pH 6.0, Dosage $0.1 \mathrm{~g}$, temperature $300 \mathrm{~K}$, contact time $120 \mathrm{~min}$ ) 


\section{Effect of adsorbent dose}

The adsorbent dose affects the number of sites available for binding metals in a solution. In this study, five different adsorbent dosages were selected ranging from 0.1 to $0.5 \mathrm{~g}$ while the lead and cadmium concentrations were fixed at 200 $\mathrm{mg} / \mathrm{L}$. The effect of adsorbent dosage on the percentage removal and adsorption capacity of $\mathrm{Pb}$ (II) and $\mathrm{Cd}$ (II) ions are shown in Fig. 6. It was observed that percentage removal of $\mathrm{Pb}$ (II) increased from 50.45 to $68.76 \%$ and 78.43 to $91.78 \%$ for $\mathrm{KC}$ and SDKC respectively and also removal of Cd (II) increased from 44.30 to $60.55 \%$ and 76.20 to $89.93 \%$ for $\mathrm{KC}$ and SDKC respectively with increase in adsorbent

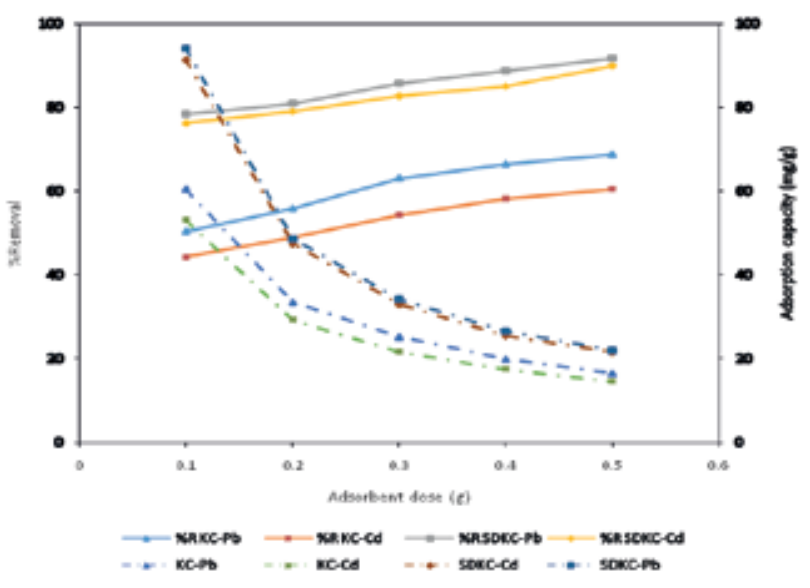

Fig. 6. Effect of adsorbent dose on the adsorption of heavy metals (pH 6.0, metal concentration $200 \mathrm{mg} / \mathrm{L}$, temperature $300 \mathrm{~K}$, contact time $120 \mathrm{~min}$ )

dose. Such a trend is mostly attributed to an increase in the sorptive surface area and the availability of more active binding sites on the surface of the adsorbent (Nasuha , 2010). However, the equilibrium adsorption capacity showed an opposite trend. As the adsorbent dosage was increased from 0.1 to $0.5 \mathrm{~g}$, there was a decrease in adsorption capacity of $\mathrm{Pb}$ (II) from 60.54 to $16.50 \mathrm{mg} / \mathrm{g}$ and 94.12 to $22.03 \mathrm{mg} / \mathrm{g}$ for $\mathrm{KC}$ and SDKC respectively and also decrease in adsorption capacity of Cd (II) from 53.16 to $14.53 \mathrm{mg} / \mathrm{g}$ and 91.44 to $21.58 \mathrm{mg} / \mathrm{g}$ for $\mathrm{KC}$ and SDKC respectively. This may be due to the decrease in total adsorption surface area available to lead and cadmium ions resulting from overlapping or aggregation of adsorption sites (Crini, 2007; Akar, 2009). This decrease in equilibrium adsorption capacity per unit mass of adsorbent may also be due to the higher adsorbent dose providing more active adsorption sites, which results in the adsorption sites remaining unsaturated during the adsorption reaction $(\mathrm{Li}, 2011)$. The adsorption trend of metal ions on the adsorbents was also in the order $\mathrm{SDKC}>\mathrm{KC}$, while that for metal ions was $\mathrm{Pb}>\mathrm{Cd}$. The adsorbent dose of $0.1 \mathrm{~g}$ was chosen in this study due to its high adsorption capacity for metal ions recorded.

\section{Effect of Agitation time}

The time it takes metal ions and adsorbent to reach equilibrium is of considerable importance in adsorption experiment because it depends on the nature of the system used and can provide information on the process mechanism. The effect of agitation time on the percentage removal of the heavy metals from the solution was studied as shown in Fig. 7. An increase in percentage removal of the metal ions with increase in contact time was recorded. The fast adsorption at the initial stages is attributed to an increased availability in the number of available active sites on the adsorbents. The sorption rapidly occurs and is controlled by the diffusion process from the bulk to the surface of the adsorbent. In the later stages the adsorption diminished and attained equilibrium due to the utilization and subsequent saturation of the active sites, the sorption in this stage is likely an attachment controlled process due to less available adsorption sites (Das and Mondal, 2011). Similar findings for lead (II) adsorption onto other adsorbents have been reported by other investigators (Badmus et al., 2007). It was also observed that different equilibrium times were attained for the two metal ions on all the adsorbents. Equilibrium sorption time of 50 and 40 min were obtained for $\mathrm{Pb}$ (II) and $\mathrm{Cd}$ (II) ions on the adsorbents respectively. A contact time of $120 \mathrm{~min}$ was utilized in this study to ensure equilibrium sorption of both metal ions on all the adsorbents was attained. The faster rate of adsorption of $\mathrm{Cd}$ (II) when compared to $\mathrm{Pb}$ (II) is due to the smaller ionic radii of $\mathrm{Cd}$ (II) $(0.097 \mathrm{~nm})$ than $\mathrm{Pb}$ (II) (0.12 $\mathrm{nm}$ ) which makes it to diffuse faster to the surface of adsorbents due to its smaller size than the bulkier $\mathrm{Pb}$ (II) ion (Akpomie and Dawodu, 2014).

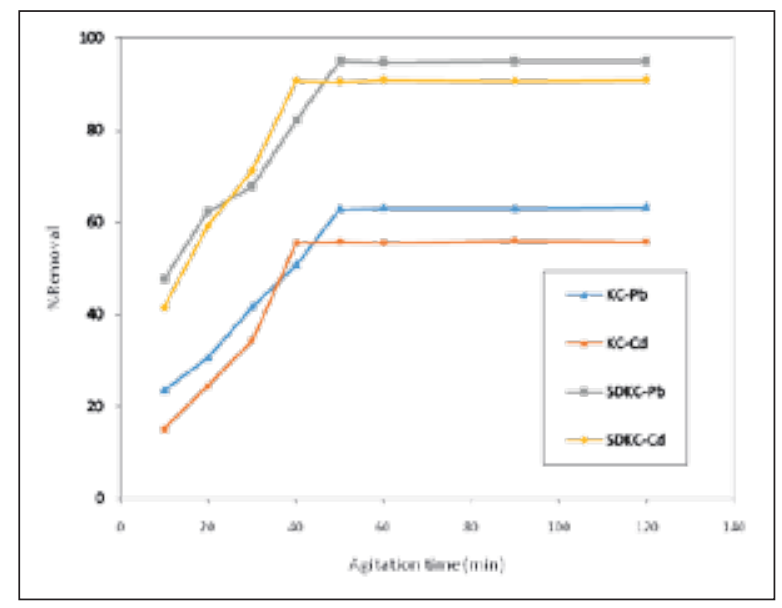

Fig. 7. Effect of agitation time on the percentage removal of heavy metals ( $\mathrm{pH} 6.0$, dosage $0.1 \mathrm{~g}$, metal concentration $200 \mathrm{mg} / \mathrm{L}$, temperature $300 \mathrm{~K}$, 
Table 1. A comparison of the Langmuir, Freundlich, Tempkin, Dubinin-Radushkevich (D-R), Scatchard and FloryHuggins isotherm constants for the adsorption of $\mathrm{Pb}(\mathrm{II})$ and $\mathrm{Cd}(\mathrm{II})$ ions unto $\mathrm{KC}$ and $\mathrm{SDKC}$

\begin{tabular}{|c|c|c|c|c|}
\hline \multirow[b]{2}{*}{ Isotherm models } & \multicolumn{2}{|c|}{$\mathrm{KC}$} & \multicolumn{2}{|c|}{ SDKC } \\
\hline & $\mathrm{Pb}(11)$ & $\mathrm{Cd}(11)$ & $\mathrm{Pb}(11)$ & $\mathrm{Cd}(11)$ \\
\hline \multicolumn{5}{|l|}{ Langmuir } \\
\hline $\mathrm{q}_{\mathrm{L}}(\mathrm{mg} / \mathrm{g})$ & 125 & 125 & 142.86 & 125 \\
\hline $\mathrm{K}_{\mathrm{L}}(\mathrm{L} / \mathrm{mg})$ & $3.5 \times 10^{-3}$ & $2.4 \times 10^{-3}$ & $2.7 \times 10^{-2}$ & $2.4 \times 10^{-5}$ \\
\hline $\mathrm{R}^{2}$ & 0.998 & 0.987 & 0.994 & 0.998 \\
\hline \multicolumn{5}{|l|}{ Freundlich } \\
\hline $\mathrm{K}_{\mathrm{F}}$ & 2.54 & 1.46 & 21.09 & 16.26 \\
\hline $1 / \mathrm{n}$ & 0.547 & 0.616 & 0.301 & 0.331 \\
\hline $\mathrm{N}$ & 1.83 & 1.62 & 3.32 & 3.02 \\
\hline $\mathrm{R}^{2}$ & 0.985 & 0.992 & 0.951 & 0.907 \\
\hline \multicolumn{5}{|l|}{ Tempkin } \\
\hline A (L/g) & 0.035 & 0.024 & 0.630 & 0.345 \\
\hline B (mg/g) & 26.00 & 26.58 & 21.80 & 22.86 \\
\hline $\mathrm{R}^{2}$ & 0.997 & 0.985 & 0.991 & 0.973 \\
\hline \multicolumn{5}{|l|}{ Dubinin-Radushkevich } \\
\hline $\mathrm{qm}(\mathrm{mg} / \mathrm{g})$ & 68.306 & 62.802 & 100.283 & 98.003 \\
\hline$\beta\left(\mathrm{mol}^{2} / \mathrm{J}^{2}\right)$ & & 0.001 & $2.0 \times 10^{-5}$ & $6.0 \times 10^{-5}$ \\
\hline $\mathrm{R}^{2}$ & $\overline{0} .895$ & 0.885 & 0.879 & 0.935 \\
\hline \multicolumn{5}{|l|}{ Scatchard } \\
\hline $\mathrm{q}_{\mathrm{s}}(\mathrm{mg} / \mathrm{g})$ & 147.333 & 152.000 & 121.930 & 124.958 \\
\hline $\mathrm{b}(\mathrm{L} / \mathrm{mg})$ & 0.003 & 0.002 & 0.043 & 0.024 \\
\hline $\mathrm{R}^{2}$ & 0.996 & 0.974 & 0.960 & 0.960 \\
\hline \multicolumn{5}{|l|}{ Flory-Huggins } \\
\hline $\mathrm{K}_{\mathrm{FH}}$ & $4.80 \times 10^{-5}$ & $2.66 \times 10^{-5}$ & $2.80 \times 10^{-4}$ & $2.20 \times 10^{-4}$ \\
\hline $\mathrm{n}_{\mathrm{FH}}$ & -4.123 & -5.636 & -0.927 & -1.188 \\
\hline $\mathrm{R}^{2}$ & 0.995 & 0.991 & 0.981 & 0.963 \\
\hline
\end{tabular}

\section{Equilibrium isotherm analysis}

In order to effectively analyze and design an adsorption process it is important to understand the equilibrium isotherm application. Adsorption isotherms provide basic physicochemical data for evaluating the applicability of the adsorption process as a unit operation. In this study, Langmuir, Freundlich, Temkin, Dubinin-Radushkevich (D-R), Scatchard and Flory-Huggins isotherms were applied to the experimental data. The regression coefficient $\left(\mathrm{R}^{2}\right)$ was utilized to determine the best fitted model and the closer the $\mathrm{R}^{2}$ value to 1 , the best the model fit. The equilibrium isotherm parameters calculated are presented in Table I. Higher $\mathrm{R}^{2}$ values $(>0.962)$ were obtained in Langmuir as well as in Temkin and Flory-Huggins indicating that the models gave good fit to the adsorption data. Furthermore, higher $\mathrm{R}^{2}$ value of Langmuir depicts that sorption process is attributed to a monolayer adsorption on a homogeneous surface. However, the Langmuir dimensionless separation factor $\left(R_{L}\right)$ values obtained for the two metal ions with initial metal concentration from 200 to $1000 \mathrm{mg} / \mathrm{L}$ is in the range of 0.04 -0.74 for $\mathrm{Pb}$ (II) and $0.03-0.99$ for $\mathrm{Cd}$ (II)indicating that the adsorption of the $\mathrm{Pb}$ (II) and $\mathrm{Cd}$ (II) unto $\mathrm{KC}$ and SDKC are favorable processes. The Langmuir equilibrium constant $\left(K_{L}\right)$ of $\mathrm{KC}$ for $\mathrm{Pb}$ (II) and $\mathrm{Cd}$ (II) are $3.5 \times 10^{-3}$ and $2.4 \times$ $10^{-3} \mathrm{~L} / \mathrm{mg}$ respectively, while that of SDKC for $\mathrm{Pb}$ (II) and $\mathrm{Cd}$ (II) are $2.7 \times 10^{-2}$ and $2.4 \times 10^{-5} \mathrm{~L} / \mathrm{mg}$ respectively.

On the other hand, Freundlich, Dubinin-Radushkevich (D-R), and Scatchard generally gave low $\mathrm{R}^{2}$ values indicating that the models did not fit in well to the adsorption data, except for the adsorption of $\mathrm{Cd}$ (II) unto $\mathrm{KC}$ in Freundlich and also $\mathrm{Pb}$ (II) unto $\mathrm{KC}$ in Scatchard which showed high values of $\mathrm{R}^{2}$. While the fitness in Freundlich suggests heterogeneous multilayer adsorption of $\mathrm{Cd}$ (II) unto $\mathrm{KC}$, the fitness in Scatchard as a result of high linearity obtained from the Scatchard plot of qe/Ce against qe suggests homogeneous monolayer adsorption of $\mathrm{Pb}$ (II) unto $\mathrm{KC}$ and as well confirms the good fit to the experimental data obtained by the Langmuir model.

\section{Kinetic model analysis}

Kinetic analysis helps in the prediction of the mechanism involved in sorption and identification of the rate limiting step of the process (Das and Mondal, 2011). The pseudo-first order, pseudo-second order, Elovich equation and intraparticle diffusion models were applied to evaluate kinetic 
Table II. A comparison of the pseudo-first order, pseudo-second order, elovich equation and intraparticle diffusion constants for the adsorption of $\mathrm{Pb}(\mathrm{II})$ and $\mathrm{Cd}(\mathrm{II})$ ions unto $\mathrm{KC}$ and $\mathrm{SDKC}$

\begin{tabular}{|c|c|c|c|c|}
\hline \multirow[t]{2}{*}{ Kinetic models } & \multicolumn{2}{|l|}{$\mathrm{KC}$} & \multicolumn{2}{|l|}{ SDKC } \\
\hline & $\mathrm{Pb}(11)$ & $\mathrm{Cd}(11)$ & $\mathrm{Pb}(11)$ & $\mathrm{Cd}(11)$ \\
\hline $\begin{array}{l}\mathrm{qe}_{\text {exp }}(\mathrm{mg} / \mathrm{g}) \\
\text { Pseudo-first-order }\end{array}$ & 25.32 & 22.38 & 37.98 & 36.36 \\
\hline $\mathrm{qe}_{\mathrm{cal}}(\mathrm{mg} / \mathrm{g})$ & 38.99 & 77.09 & 57.68 & 23.88 \\
\hline $\mathrm{K}_{\mathrm{I}}\left(\min ^{-1}\right)$ & 0.074 & 0.113 & 0.094 & 0.083 \\
\hline $\mathrm{R}^{2}$ & 0.761 & 0.825 & 0.708 & 0.628 \\
\hline \multicolumn{5}{|c|}{ Pseudo-second-order } \\
\hline $\mathrm{h}(\mathrm{mg} / \mathrm{g} \min )$ & 1.39 & 1.00 & 3.48 & 3.80 \\
\hline $\mathrm{K}_{2}(\mathrm{~g} / \mathrm{mg} \min )$ & $1.33 \times 10^{-3}$ & $1.09 \times 10^{-3}$ & $1.84 \times 10^{-3}$ & $2.19 \times 10^{-3}$ \\
\hline $\mathrm{qe}_{\mathrm{cal}}(\mathrm{mg} / \mathrm{g})$ & 32.26 & 30.30 & 43.48 & 41.67 \\
\hline $\mathrm{R}^{2}$ & 0.970 & 0.916 & 0.990 & 0.988 \\
\hline \multicolumn{5}{|l|}{ Elovich equation } \\
\hline$\alpha(\mathrm{mg} / \mathrm{g} \min )$ & 2.620 & 1.896 & 8.625 & 8.058 \\
\hline$\beta(\mathrm{g} / \mathrm{min})$ & 0.1330 & 0.1322 & 0.1161 & 0.1166 \\
\hline $\mathrm{R}^{2}$ & 0.884 & 0.819 & 0.886 & 0.828 \\
\hline \multicolumn{5}{|c|}{ Intraparticle diffusion } \\
\hline $\mathrm{K}_{\mathrm{d}}\left(\mathrm{mg} / \mathrm{g} \min ^{1 / 2}\right)$ & 2.235 & 2.195 & 2.548 & 2.448 \\
\hline $\mathrm{C}$ & 4.669 & 2.581 & 14.55 & 14.54 \\
\hline $\mathrm{R}^{2}$ & 0.790 & 0.697 & 0.783 & 0.682 \\
\hline
\end{tabular}

data. The calculated constants obtained from these models are given in Table II. It was observed from the linear regression coefficient $\left(\mathrm{R}^{2}\right)$ values that the adsorption process showed a greater conformity to the pseudo-second order model than the pseudo-first order modeling the adsorption of $\mathrm{Pb}$ (II) and $\mathrm{Cd}$ (II) ions on the adsorbents, as $\mathrm{R}^{2}$ values were all greater than 0.9. Also the values of $q e_{c a l}$ were closer to the values of $q e_{e x p}$ than those presented by the pseudo-first order model. This good fit presented by the pseudo-second order model implies that chemisorptions mechanism is the rate controlling step for the sorption of these metal ions on the adsorbents (Barka et al, 2013). However, in this study, Elovich equation was found to present a poor fit to the sorption experiment as revealed by its highest $\mathrm{R}^{2}$ value of 0.886 , even though several researchers have found the Elovich model to be more suitable in the description of kinetic mechanism of sorption (Wu et al., 2009; Piccin et al., 2012).

The pseudo-first order, pseudo-second order and Elovich equation models could not identify the diffusion mechanism, therefore the kinetic result was further analyzed with the intraparticle diffusion model. The low $\mathrm{R}^{2}$ values presented by the intraparticle diffusion model suggest that this mechanism did not play a major role in the overall sorption of the metal ions.

\section{Thermodynamic analysis}

The result on the effect of temperature on the simultaneous adsorption of $\mathrm{Pb}(\mathrm{II})$ and $\mathrm{Cd}(\mathrm{II})$ ions unto $\mathrm{KC}$ and $\mathrm{SDKC}$ is presented in Fig.8 A slight increase in the percentage removal and adsorption capacity of both metal ions with $\mathrm{KC}$ was observed while no significant increase was observed with SDKC, with increase in solution temperature from 300 to $323 \mathrm{~K}$. This indicates that a high temperature favors the adsorption of both metal ions unto KC. The improved adsorption capability with increasing temperature suggests that the adsorption is an endodermic one. This may due to the creation of more additional adsorption sites on the adsorbent surface with increase in temperature as a result of the

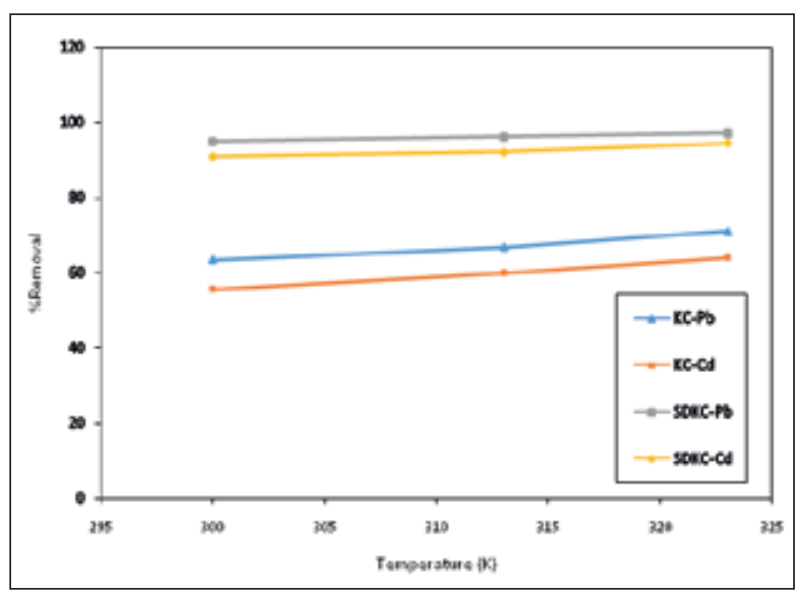

Fig. 8. Effect of solution temperature on the percentage removal of heavy metals ( $\mathrm{pH} 6.0$, dosage $0.1 \mathrm{~g}$, metal concentration $200 \mathrm{mg} / \mathrm{L}$, contact time $120 \mathrm{~min}$,) 
Table III. Comparison of thermodynamic parameters for the adsorption of $\mathrm{Pb}$ (II) and $\mathrm{Cd}(\mathrm{II})$ ions from solution unto $\mathrm{KC}$ and SDKC

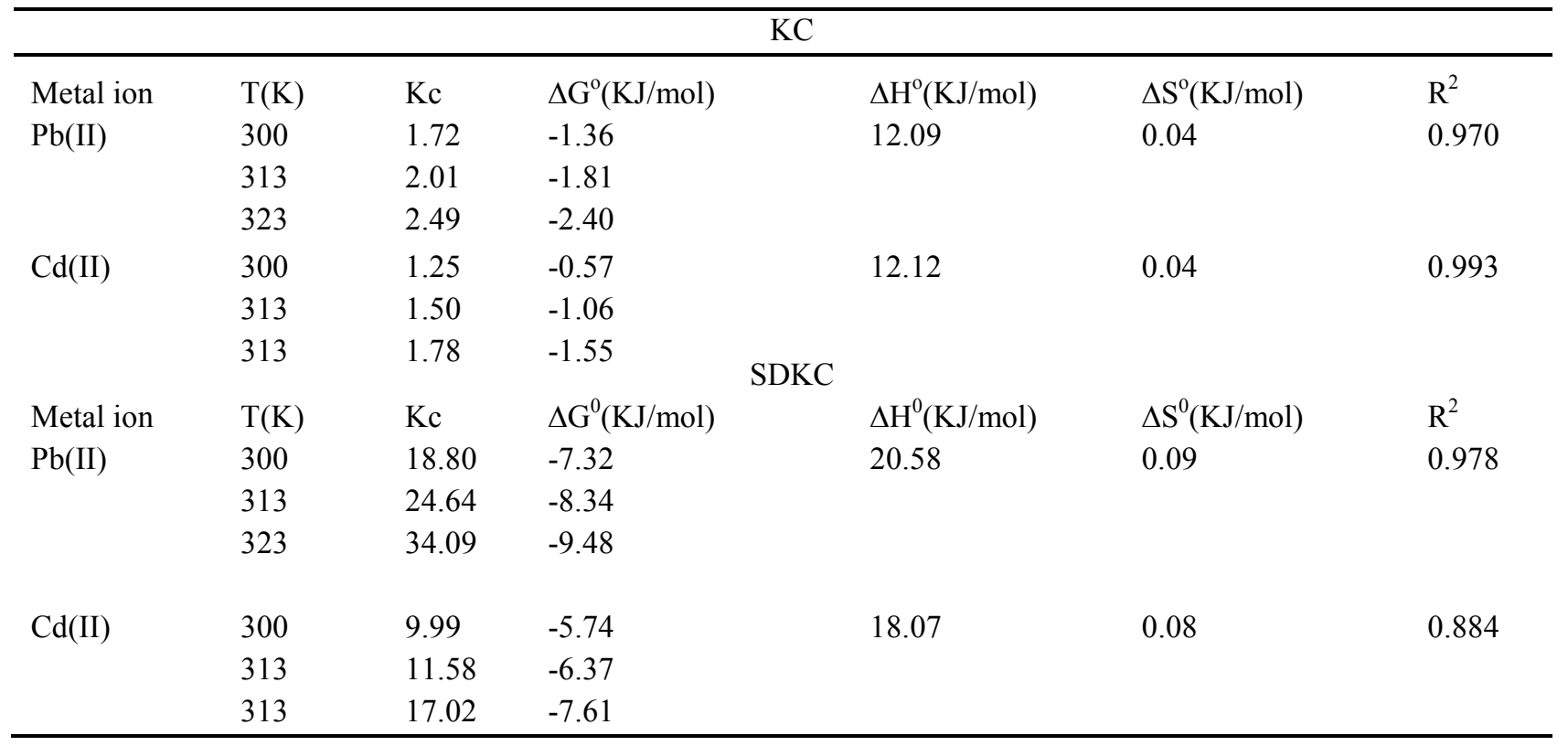

dissociation of some of the surface components on $\mathrm{KC}$ (Bhattacharyya and Gupta, 2006)

The designer of an adsorption system usually takes into account changes in the reaction based on thermodynamics. The parameters, enthalpy change $\left(\Delta H^{\circ}\right)$, entropy change $(\Delta$ $\left.S^{\circ}\right)$ and standard free energy $\left(\Delta G^{\circ}\right)$, denote the features of the final state of the system and their values are shown in Table III. The positive values of $\Delta H^{\circ}$ obtained for both metal ions with $\mathrm{KC}$ and SDKC indicate an endothermic adsorption process, which explains the fact that adsorption efficiency increased with increase in temperature. The magnitude of the enthalpy change $\left(\Delta H^{\circ}\right)$ provides information about the type of sorption. The heat evolved during physisorption generally lies in the range of $2.1-20.9 \mathrm{~kJ} / \mathrm{mol}$, while the heat of chemisorptions generally falls in the range of $80-200 \mathrm{~kJ} / \mathrm{mol}$ (Liu and Liu, 2008). From table III, the values of $\Delta H^{\circ}$ for $\mathrm{Pb}$ (II) and $\mathrm{Cd}$ (II) ions with $\mathrm{KC}$ are 12.09 and $12.12 \mathrm{~kJ} / \mathrm{mol}$, while that of SDKC are 20.58 and $18.07 \mathrm{~kJ} / \mathrm{mol}$, representing physisorption process. The positive values of $\Delta S^{\circ}$ for both metal ions indicate an increase in randomness at the solid/liquid interface during the sorption process (Guler and Sarioglu, 2013). The negative values of $\Delta G^{\circ}$ obtained for both metal ions at all temperatures indicate the spontaneous nature of the adsorption process (Meitei and Prasad, 2013). The magnitude of the free energy change $\Delta G^{\circ}$ can be used to classify adsorption as physical or chemical: the free energy change for physical adsorption is -20 and $0 \mathrm{~kJ} / \mathrm{mol}$, while that for chemical adsorption is -80 to $-400 \mathrm{~kJ} / \mathrm{mol}$ [40]. Therefore, $\Delta G^{\text {o}}$ values obtained indicate a physical adsorption process with $\mathrm{KC}$ and SDKC for both metal ions. Physical adsorption is desirable because there is a lower energy barrier to be overcome by metal ions, which allows easy desorption from the surface of the adsorbent during recycling (Dawodu and Akpomie, 2014).

\section{Conclusions}

The removal of heavy metals from aqueous solution was carried out by batch adsorption technique using $\mathrm{KC}$ and SDKC, as a low-cost adsorbents. These adsorbents which are present in great amount in Eastern Nigeria can be utilized for treatment of solution containing high concentration of $\mathrm{Pb}$ (II) and $\mathrm{Cd}(\mathrm{II})$ ions, hence reducing the toxic effects they pose to the environment. Solution $\mathrm{pH}$, initial metal concentration, agitation time, adsorbent dose, and temperature were the determining factors in adsorption. Optimum removal of both metal ions was obtained at a $\mathrm{pH}$ of 6.0 , agitation time of 120 min and an adsorbent particle size of $100 \mu \mathrm{m}$. The Langmuir, Temkin and Flory-Huggins models showed a better fit with higher $\mathrm{R}^{2}$ values than those of Freundlich, Dubinin-Radushkevich (D-R) and Scatchard models. The analysis showed that the adsorption process followed pseudo second order model. The calculated thermodynamic parameters showed an endothermic, spontaneous and a physisorption process between both metal ions and the adsorbents. The research generally revealed that the addition of sawdust to kaolinite clay enhanced its adsorption capacity for lead and cadmium ions and therefore could be efficiently utilized for the removal of the metal ions. 
This provides a cheaper alternative means of clay modification rather than the excessively used chemical means which is expensive and noxious to the environment.

\section{References}

Abdelwahab O and Amin NK (2013), Adsorption of phenol from aqueous solution by luffa cylindrical fibers: kinetics, isotherm and thermodynamic studies, Egypt $J$ Aquat Res. 39: 215-23.

Ahluwalia SS and Goyal D ( 2007), Microbial and plant derived biomass for removal of heavy metals from wastewater, Bioresour Technol 98: 2243-57.

Ahmad (2009), Removal of $\mathrm{Cu}$ (II) and $\mathrm{Pb}$ (II) ions from aqueous solutions byadsorption onto sawdust of meranti wood, Desalination 247 (1-3): 636-646.

Akar ST (2009), Biosorption of a reactive textile dye from aqueous solutions utilizing an agro-waste, Desalination 249(2): 757-761.

Akpomie KG and Dawodu FA (2014), Efficient abstraction of nickel (II) and manganese(II)from solution unto an alkaline-modified montmorillonite, Journal of Taibah University Science 8(4): 134-147. DOI:org/10. 1016/j.jtusci.2014.05.001

Akpomie KG and Dawodu FA (2014b), Montmorillonite-rice husk composite for heavy metal sequestration from binary aqua media: a novel adsorbent, Transactions of the Royal Society of South Africa. 54: 32-39. DOI:org/10. 1080/0035 919X.2014.984259

Akpomie GK, Ogbu IC, Osunkunle AA, Abuh MA and Abonyi MN (2012), Equilibrium Isotherm Studies on The Sorption of $\mathrm{Pb}$ (II) From Solution By Ehandiagu Clay, J.Emerg. Trend. Eng. App. Sc. 3: 354-358.

AOAC (2005), Official methods of analysis. $20^{\text {th }} \mathrm{Ed}$. Maryland: AOAC International.

Badmus MAO, Audu TOK and Anyata BU (2007), Removal of lead ion from industrial wastewaters by activated carbon prepared from periwinkle Shells (Typanotonusfuscatus), Turkish J. Eng. Env. Sci. 31(4): 251-263.

Barbier F, Duc GK and Petit-Ramel M (2000), Adsorption of Lead and Cadmium Ions From aqueous solution to The Montmorrillonite/Water Interface, Colloid. Surf. A: Physicochem. Eng. Aspects 166: 153-159. DOI:org/10. 1016/S0927-7757(99)00501-4

Barka N, Abdennouri M, Makhfouk ME and Qouezal S (2013), Biosorption characteristics of cadmium and lead onto eco-friendly dried cactus (opuntia ficusindica) cladodes, Journal of Environmental Chemical Engineering 1: 144-149. DOI:org/10.1016/ S1383-5866(03)00220-X
Bhattacharyya KG and Gupta SS (2006), Kaolinite, montmorillonite and their modified derivatives as adsorbents for removal of $\mathrm{Cu}(\mathrm{II})$ from aqueous solution, Sep. Purif. Technol. 50: 388-397. DOI:org/10.1016/j.seppur.2005.12.014

BIS (1981), Tolerance limits for industrial effluents prescribed by Bureau of Indian Standards, IS 2490 (Part I), New Delhi. DOI: 10.1021/ie00026a022

Biserka B and Boris S (2004), Kinetic Analysis of The Exchange Process Between Sodium Ions From Zeolite A and Cadmium, Copper and Nickel Ions From Solution, Separa. Purif. Technol 37: 17-31. DOI:org/10. 1016/S1383-5866(03)00220-X

Brigatti MF, Lugli C and Poppi L (2000), Kinetics of Heavy Metal Removal and Recovery in Sepiolite, Appl. Clay. Sci. 16: 45-57. DOI:org/10.1016/S0169-1317 (99)00046-0

Chantawong V, Harvey NW and Bashkin VN (2001), Adsorption of Lead Nitrate on Thai-Kaolin and Ball-clay, Asian. J. Energy. Environ 2: 33-48.

Crini G (2007), Removal of C.I. Basic Green 4 (Malachite Green) from aqueous solutions by adsorption using cyclodextrin based adsorbent: kinetic and equilibrium studies, Sep. Purif. Technol. 53(1): 97-110. DOI:org/10. 1016/j.seppur.2006.06.018

Das B and Mondal NK (2011), Calcareous Soil as a New Adsorbent to Remove Lead From Aqueous Solution: Equilibrium, Kinetic and Thermodynamic Study, Uni. J. Environ. Res. Technol 1: 515-530.

Dawodu FA and Akpomie (2014), Simultaneous adsorption of $\mathrm{Ni}(\mathrm{II})$ and $\mathrm{Mn}(\mathrm{II})$ ions from aqueous solution unto a Nigerian kaoliniteclay, J. Mater. Res. Technol 3: 129-141.

Echeverria JC, Zarranz I, Estella J and Garrido JJ (2005), Simultaneous effect of $\mathrm{pH}$, temperature, ionic strength and initial concentration on the retention of lead on illite, Appl. Clay Sci. 30: 103-15.

El-Eswed B, Alshaaer M and Khalili F (2012), Adsorption of $\mathrm{Cu}$ (II), Ni (II), $\mathrm{Zn}$ (II), Cd (II) and $\mathrm{Pb}$ (II) onto kaolin/zeolite based-geopolymers, Advances in Materials Physics and Chemistry 2: 119-125.

Farghali AA, Bahyat M, Allah AE and Khedr MH (2013), Adsorption of $\mathrm{Pb}$ (II) ions from aqueous solution using copper oxide nano structures, Beni-Suef University Journal of Basic and Applied Sciences 2: 61-71. DOI:org/10.1016/j.bjbas.2013.01.001

Guerra DJL, Mello I, Resende R and Silva R (2013), Application as adsorbents of natural and functionalized Brazilian bentonite in $\mathrm{Pb}$ (II) adsorption: equilibrium, kinetic, $\mathrm{pH}$ and 
thermodynamic effects, Water Resources and Industry 4: 32-50. DOI:org/10.1016/j.wri.2013.11.001

Guler UA and Sarioglu M (2013), Single and binary biosorption of $\mathrm{Cu}, \mathrm{Ni}$ and methylene blue by raw and pretreated Spirogyra sp.: equilibrium and kinetic modeling, J Environ Chem Eng. 1: 269-377.

Jianlong W, Xinmin Z, Decai D and Ding Z (2001), Biosorption of Lead (II) From Aqueous Solution By Fungal Biomass of Aspergillus Niger, J. Biotechnol 87: 273-277.

Kikuchi (2006), Effect of $\mathrm{ZnO}$ loading to activated carbon on $\mathrm{Pb}$ (II) adsorption from aqueous solution, Carbon 44(2): $\quad$ 195-202. DOI:org/10.1016/j.carbon. 2005.07.040

Kiran I, Akar T and Tunali S (2005), Biosorption of Pb (II) \& $\mathrm{Cu}(\mathrm{II})$ From Aqueous Solution By Pretreated Biomass of Neurospors Crassa, Process Biochem 40: 3550-3558. DOI:org/10.1016/j.procbio.2005.03.051

Kumar M and Tamilarasan R (2013), kinetics equilibrium data and modeling studies for the sorption of chromium by prosopis julidlora bark carbon, Arab. J. chem. 6: 59-67. DOI:org/10.1016/j.arabjc.2013.05.025

Lalhruaitluanga H, Jayaram K, Prasad MNV and KK (2010), Lead (II) adsorption from aqueous solutions by raw and activated charcoals of Melocanna baccifera Roxburgh (bamboo) - a comparative study, J. Hazard. Mater. 175: 311-318. DOI:org/10.1016/j.jhazmat.2009.10.005

Langmuir I (1918), The adsorption of gases on plane surfaces of glass, mica and platinum, J Amer Chem Soc. 40: 1361-403.

Li T, Liu Y, Peng Q, Hua X, Liao T and Wanga H (2013), Removal oflead (II) from aqueous solution with ethylenediamine-modified yeast biomass coated with magnetic chitosan microparticles: kinetic and equilibrium modeling, Chemical Engineering Journal 214: 189-197.

Li Y, Xia B, Zhao Q, Liu F, Zhang P, Du Q, Wang D, Li D, Wang Z and Xia Y (2011), Removal of copper ions from aqueous solution by calcium alginate immobilized kaolin, J. Environ. Sci. 23: 404-411. DOI:org/10.1016/S1001-0742(10)60442-1

Low MJD (1960), Kinetics of chemisorptions of gases on solids. Chem Rev. 60: 267-312. DOI: 10.1021/ cr60205a003

Malik DJ (2002), Characterisation of novel modified active carbons and marine algal biomass for the selective adsorption of lead, Wat. Res. 36(6): 1527-1538.

Marshal WE and Champagne ET (1995), Agricultural Byproducts as Adsorbents For Metal Ions in
Laboratory Prepared Solutions and in Manufacturing Wastewater, J. Environ. Sci. Health 30: 241-261.

Meitei MD and Prasad MNV (2013), Pb(II) and Cd(II) biosorption onSpirodela polyhiza Scheleiden biomass, J. Environ. Chem. Eng. 1: 200-207.

Naseem R and Tahir SS (2001), Removal of Pb(II) From Aqueous/ Acidic Solutions By Using Bentonite As an Adsorbent, Water. Res. 35: 3982-3986.

Nasuha N (2010), Rejected tea as a potential low cost adsorbent for the removal of methylene blue, $J$. Hazard. Mater. 175(1-3): 126-132.

Nessim RB, Bassioung AR, Zaki HR, Moawad MN and Kandeel KM (2014), Biosorption of $\mathrm{Pb}$ and $\mathrm{Cd}$ using marine algae, Chemistry and Ecology 27(6): 579-594.

Piccin JS, Gomes CS, Feris LA and Gutterres M (2012), Kinetics and isotherms of leather dye adsorption by tannery solid waste, Chem. Eng. J. 183: 30-38.

Politi D and Sidiras D (2012), Wastewater treatment for dyes and heavy metals usingmodified pine sawdust as adsorbent, Procedia Engineering 42: 1969-1982. DOI:org/10.1016/j.proeng.2012.07.593

Sari A and Tuzen M (2009), Kinetic and equilibrium studies of biosorption of $\mathrm{Pb}$ (II) and $\mathrm{Cd}$ (II) from aqueous solution by macrofungus (Amanita rubescens) biomass, J. Hazard. Mater 164: 1004-1011.

Shukla SR and Roshan SP (2005), Adsorption of Cu(II), $\mathrm{Ni}(\mathrm{II})$ and $\mathrm{Zn}$ (II) on dye loaded groundnut shells and sawdust, Sep. Purif. Technol 42: 1-8. DOI:org/ 10.1016/j.seppur.2004.09.003

Solisio C, Lodi A, Soletto D and Converti A (2008), Cadmium biosorption on Spirulina platensis biomass, Bioresour, Techno 99: 5933-5937.

Taffarel SR and Rubio J (2009), On the removal of Mn(II) ions by adsorption onto natural and activated Chilean zeolites, Miner. Eng, 22: 336-343. DOI:org/10. 1016/j.mineng.2008.09.007

Ucun H, Bayhan YK, Kaya Y, Cakici A and Algur OF (2003), Biosorption of Lead (II) From Aqueous Solution By Cone Biomass of Pinus Sylvestris, Desalination 154: 233-238. DOI:org/10.1016/S00119164(03)80038-3

Unuabonah EI (2007), Kinetic and thermodynamics of the adsorption of some heavy metal ions on modified kaolinite clay, Ph.D Thesis, Department of Chemistry, University of Ibadan, Nigeria.

Wu FC, Tseng RL and Juang RS (2009), Characteristics of Elovichequation used for analysis of adsorption kinetics in dye chitosansystems, Chem. Eng. J. 150: 366-373. DOI:org/10.1016/j.cej.2009.01.014 